\title{
Monoclonal antibodies against human astrocytomas and their reactivity pattern*
}

\author{
D. Stavrou ${ }^{1}$, E. Keiditsch ${ }^{1}$, F. Schmidberger ${ }^{2}$, K. Bise ${ }^{3}$, I. Funke ${ }^{4}$, \\ W. Eisenmenger ${ }^{5}$, R. Kurrle ${ }^{6}$, B. Martin ${ }^{1}$ and U. Stocker ${ }^{1}$ \\ ${ }^{1}$ Institute of Pathology, Dept. of Clinical and Experimental Neuro-Oncology, ${ }^{2}$ Dept. of Neurosurgery, Clinicum \\ Bogenhausen, Teaching Hospital of the Technical University of Munich, ${ }^{3}$ Institute of Neuropathology, ${ }^{4}$ Institute \\ of Immunology, ${ }^{5}$ Institute of Legal Medicine, University of Munich and ${ }^{6}$ Behringwerke AG, Marburg (F.R.G.)
}

(Received 14 November, 1986)

(Revised, received 26 March, 1987)

(Accepted 26 March, 1987)

\section{SUMMARY}

The establishment of hybridomas after fusion of X63-Ag8.653 mouse myeloma cells and splenocytes from BALB/c mice hyperimmunized against human astrocytomas is presented. The animals were primed with $5 \times 10^{6}$ chemically modified uncultured or cultured glioma cells. Six weeks after the last immunization step an intrasplenal booster injection was administrated and 3 days later the spleen cells were prepared for fusion experiments. According to the specificity analysis of the generated antibodies 7 hybridoma products (MUC 7-22, MUC 8-22, MUC 10-22, MUC 11-22, MUC 14-22, MUC 15-22 and MUC 2-63) react with gliomas, neuroblastomas and melanomas as well as with embryonic and fetal cells but do not recognize non-neurogenic tumors. The selected monoclonal antibodies ( $\mathrm{McAbs}_{\text {) of }} \mathrm{IgG}_{1}$ and $\mathrm{IgG}_{2 \mathrm{a}}$ isotypes are not extensively characterized but these antibodies have been demonstrated to be reactive with a panel of glioma cell lines with varying patterns of antigen distribution. Using the McAbs described above and a series of cryosections of glioma biopsies and paraffin sections of the same material as well as glioma cultures established from these, variable antigenic profiles among glioma cell populations could be demonstrated. From these results it is evident that there is not only a distinct degree of antigenic heterogeneity among and within brain tumors, but also that the pattern of antigenic expression can change continuously. Some of the glioma associated antigens recognized by the selected

* Dedicated to Prof. Dr. Dr. h.c.mult. Wilhelm Doerr, Medical Faculty, University of Heidelberg, for his interest and encouragement.

Correspondence to: Prof. Dr. Dr. med. D. Stavrou, Institute of Pathology, Clinicum Bogenhausen, Englschalkinger Str. 77, 8000 Munich 81, F.R.G.

0022-510X/87/\$03.50@1987 Elsevier Science Publishers B.V. (Biomedical Division) 
antibodies persist after fixation with methanol/acetone and Karnovsky's fixative and probably are oncoembryonic/oncofetal antigen(s). The data suggest that the use of McAbs recognizing tumor associated oncofetal antigens in immunohistochemistry facilitates objective typing of intracranial malignancies and precise analysis of fine needle brain/tumor biopsies in a sensitive and reproducible manner.

Key words: Human gliomas; Monoclonal antibodies; Immunohistochemistry; Oncofetal antigens

\section{INTRODUCTION}

The development of adequate immunologic methods is a fundamental condition for the investigation of membrane alterations and the resulting antigenicity of tumor cells. By the establishment of the hybridoma technique (Köhler and Milstein 1975) and the use of monoclonal antibodies (McAbs) in the analysis of the antigenic determinants of the tumor cell membrane, not only the existence of tumor associated antigens in spontaneous and experimental brain tumors has been demonstrated (Schnegg et al. 1981; Sikora and Phillips 1981; Coakham et al. 1982; Wikstrand and Bigner 1982; Stavrou et al. 1983; de Muralt et al. 1985), but also efforts in developing valuable diagnostic methods received considerable stimulation (review by Bullard and Bigner 1985). Numerous attempts have been made to produce McAbs which recognize glioma cells exclusively. So far, there is a number of monoclonal reagents binding antigens expressed on tumor cells but also on normal glia cells (Krajewski et al. 1986).

In order to generate molecules useful to assist in the more accurate and objective typing of intracranial malignancies we established immunoglobulin secreting hybridomas using cultured and uncultured human astrocytoma cells as antigen. In the following we describe the recognition pattern of selected McAbs with their high degree of specificity utilizing cell cultures of different origin as well as tissue samples obtained from neurogenic and non-neurogenic tumors and normal organs.

\section{MATERIALS AND METHODS}

\section{Human tumors}

Fresh tumor samples from biopsy material were immediately frozen and preserved in liquid nitrogen containers or bio-freezers until use for histochemistry or immunization. Additional tumor specimens were fixed in Bouin's solution, Karnovsky's fixative and methanol/acetone mixture and embedded in paraffin $\left(45^{\circ} \mathrm{C}\right)$. Sections of frozen and paraffin material were used for conventional histology as well as for immunohistochemistry. For control experiments tissue fragments of different regions of normal brain and other organs were obtained $90 \mathrm{~min}$ post-mortem and processed analogous. 


\section{Human tumor cell cultures}

For establishment of primary cultures, fragments of biopsy material obtained under sterile conditions were placed in Falcon flasks and covered with medium M 199 (with Hank's salts, Seromed ${ }^{\circledR}$, Berlin, F.R.G. or RPMI 1640), supplemented with $20 \%$ inactivated FBS (fetal bovine serum, Flow laboratories, Meckenheim, F.R.G.), $10 \mathrm{ml}$ $8.8 \% \mathrm{NaHCO}_{3}, 100000 \mathrm{IU}$ penicillin $\mathrm{G}, 0.1 \mathrm{~g}$ streptomycin, $0.1 \mathrm{~g}$ neomycin, and $3.4 \mathrm{ml}$ $20 \mathrm{mM}$ glutamin per litre medium. Cultures were incubated at $37^{\circ} \mathrm{C}$ in air with $6 \% \mathrm{CO}_{2}$ and high humidity. For in vitro passaging of the cells, primary cultures were splitted $1: 2$ using saline trypsin-versene (STV) solution. Long term cultures were fed with M 199 or RPMI 1640 (Seromed ${ }^{\circledR}$, Berlin, F.R.G.), supplemented with $10 \%$ inactivated FBS, $10 \mathrm{ml} 8.8 \% \mathrm{NaHCO}_{3}, 100000 \mathrm{IU}$ penicillin $\mathrm{G}, 0.1 \mathrm{~g}$ streptomycin, and $3.4 \mathrm{ml}$ (M 199) or $10 \mathrm{ml}$ (RPMI 1640) $20 \mathrm{mM}$ glutamin per litre medium and karyotyped from time to time.

\section{Human embryonic cell cultures}

Fragments from brain anlage as well as from thoracic and abdominal segments of two embryos (9th and 11th weeks of development) were layered in plastic flasks. In addition, the rest of the embryonic material was prepared as a fine cell suspension and placed in tissue culture flasks. All primary cultures were fed with $\mathrm{HC}$ medium (450 ml DMEM, 75 ml FBS, $50 \mathrm{ml}$ NCTC-135 medium, Flow Lab., Meckenheim, F.R.G., $5 \mathrm{ml}$ sodium pyruvate, $0.1 \mathrm{~g}$ neomycin) initially supplemented with $20 \%$ inactivated FBS and the subcultures were maintained in the same medium containing $10 \%$ FBS. Subsequently, the cultures were serially transferred using STV solution twice a week. All cultures were incubated at $37^{\circ} \mathrm{C}$ humidified atmosphere of $6 \% \mathrm{CO}_{2}$ in air.

\section{Animals}

BALB $/ \mathrm{c}$ and BALB/c-nu/nu mice used for immunization and production of ascitic fluid were taken from our barrier maintained colony.

\section{Mouse myeloma line}

The myeloma cell line X63-Ag8.653 (Kearney et al. 1979) was used for fusion experiments. The myeloma cells were grown in $\mathrm{HC}$ medium supplemented with $10 \%$ FBS. Two days before fusion, the cells were fed with $\mathrm{HC}$ medium containing $20 \%$ FBS.

\section{Establishment of murine hybridoma clones (MUC)}

BALB/c mice were immunized i.p. 3 times (1st, 8th, 15th day) with $5 \times 10^{6}$ TNBS (2,4,6-trinitrobenzenesulfonic acid) modified whole human tumor cells cultivated in vitro (85HG-3 and $85 \mathrm{HG}-63$ astrocytoma cells) and with cells prepared from biopsy material of a malignant glioma (N 22/85: astrocytoma grade III). TNBS modification was carried out as described by Stavrou et al. $(1980,1981)$. Briefly, mechanically harvested cells $\left(5 \times 10^{6}\right)$ in $0.1 \mathrm{ml}$ medium were incubated with $0.1 \mathrm{ml}$ of $0.1 \mathrm{M}$ TNBS dissolved in $0.05 \mathrm{M}$ PBS (pH 7.4) for $10 \mathrm{~min}$ at $37^{\circ} \mathrm{C}$. Aseptically removed tumor fragments were washed with sterile PBS, immediately minced and passed through a sterile wire-gauze. The cell suspension was frozen and stored at $-80^{\circ} \mathrm{C}$. Six weeks 
after the last immunization an intrasplenal booster injection of $5 \times 10^{5}$ native tumor cells, harvested from culture vessels using STV solution or thawed from frozen tumor samples, was performed. Three days later spleen cells were fused with X63-Ag8.653 myeloma cells. Hybrids were selected as described previously (Stavrou et al. 1983, 1985). Supernatants from hybridoma cultures were tested for antibody reactivity with glioma tissue and glioma cell cultures.

\section{Antibody binding assays}

Screening for immunoglobulin secretion by hybridomas and for identifying hybridoma clones of interest was performed using the following techniques: (a) microELISA (Posner et al. 1982); (b) indirect immunoperoxidase stain, carried out on cells grown in Terasaki plates and on tissue sections prepared from frozen as well as from fixed (methanol/acetone, Bouin, Karnovsky) and paraffin-embedded $\left(45^{\circ} \mathrm{C}\right)$ material; (c) indirect immunofluorescence test as reported by Stavrou et al. (1978); and (d) ${ }^{125}$ I radioimmunoassay ( ${ }^{125} \mathrm{I}$-RIA) using $10 \times 10^{5}$ target cells incubated on U-bottomed microtest plates with culture fluid. Details of the performance protocols have been published (Stavrou et al. 1983; de Muralt et al. 1985).

\section{Flow cytometry analysis}

Fluorescent activated cell sorter procedures were performed in buffer consisting of phosphate-buffered saline, $2.5 \%$ fetal bovine serum, and $0.02 \% \mathrm{NaN}_{3}$. Stained cells were analysed after fixation with $1 \%$ paraformaldehyde (Lanier and Warner 1981) by flow cytometry using an EPICS 752 (Coulter Electronics). The EPICS was operated at $488 \mathrm{~nm}$ excitation wavelength with the photomultipler tube at $650-800 \mathrm{~V}$. Fluorescence intensity was expressed on a log scale of 256 channels. Living cells were gated on forward angel lightscatter and 90 degree log integrated lightscatter. Indirect immunofluorescence was used for the hybridoma supernatants directed against glioma cell surface determinants. The supernatants were incubated for $60 \mathrm{~min}$ with $10^{6}$ cells on ice, followed by 2 washes with PBS, and incubated on ice with rabbit anti-mouse FITC (Dakopatts F 261).

As control, the isotype-matched irrelevant mouse myeloma protein UPC 10 (Sigma No. M-9144) diluted $1: 100$ was used.

\section{Concentration and partial characterization of $M c A b s$}

The enrichment of McAbs from hybridoma supernatants was performed by using saturated ammonium sulfate solution (Jonak 1980). The identification of hybridoma products was carried out by using the two-dimensional double-immunodiffusion, immunoelectrophoresis and SDS-PAGE tests. The isotype of monoclonal immunoglobulin was determined by using micro-Ouchterlony immunodiffusion and microtitration ELISA subtyping system (Mouse-typer ${ }^{\mathrm{TM}}$ sub-isotyping kit, Bio-Rad Laboratories, Richmond, LA, U.S.A.) and appropriate polyclonal antisera (Miles Laboratories, Naperville, IL, U.S.A.).

In order to estimate the binding specificity of selected hybridoma products a series of absorption experiments were performed. Hybridoma supernatants were absorbed 
with cultured human cells and human brain powder and the remaining activity was then tested by antibody-binding tests using cultured glioma cells as targets. For quantitative absorptions increasing numbers of glioma cells were suspended in aliquots of a constant dilution of hybridoma supernatants and after incubation the remaining activity was measured by micro-ELISA. The absorption procedures have been described in detail elsewhere (Stavrou et al. 1983).

\section{RESULTS}

\section{Establishment and selection of antibody secreting hybridomas}

From 2 fusion experiments between X63-Ag8.653 myeloma cells and immune spleen cells against glioma cells, hybrids appeared between 6 and 10 days following fusion and were seen in 151 wells of Linbro plates. Screening of the supernatants of these hybridoma cultures, composed of numerous single colonies, showed that in 24 wells hybrids were secreting antibodies reacting to glioma cells used for immunization as well as to different human target cells including embryonic cells.

\section{Specificity analysis and isotyping of interesting monoclonal immunoglobulins}

Selected hybridomas that secreted monoclonal antibodies binding to various target tumor cells were sequentially cloned 3 times by limiting dilution method. In each cloning step they were examined for specificity or cross-reactivity by testing culture supernatants for antibody binding to human tumor cells of different origin and human peripheral blood monocytes. The eleven murine clones (MUC) secreting antibodies which did not react with control cells were chosen for further specificity analysis. The selected clonal products described here were designated as MUC 1-3, MUC 2-3, MUC 3-3, MUC 4-3, MUC 5-3 and MUC 7-22, MUC 8-22, MUC 10-22, MUC 11-22, MUC 14-22, MUC 15-22 and MUC 2-63. During the specificity analysis of these 11 monoclonal anti-glioma antibodies it was observed that the hybridoma products MUC 1-3 to MUC 5-3 reacted not only with neuroectodermal tumors but also with normal brain tissue. Whereas the rest of the McAbs (MUC 7-22 to MUC 15-22 and MUC 2-63) reacted with neuroectodermal tumors but did not recognize normal brain except for a few cells in brain cortex particularly bordering on tumor tissue. In this regard it should be stressed that the antibodies MUC 7-22 to MUC 15-22 and MUC 2-63 also recognized human embryonic brain cells (Table 1).

In order to ensure the specificity of the selected hybridoma products, a series of quantitative absorption experiments using glioma cells as well as normal brain tissue were performed. A representative sample of the obtained data showed that monoclonal antibodies secreted by the hybridoma clones MUC 7-22 and MUC 8-22 did not lose their binding capability to glioma cells, including the immunizing tumor cells, after absorption with normal human brain tissue. On the other hand, the quantitative absorption with glioma cells derived from the tumor used for immunization gradually reduced the binding activity of MUC 7-22 and MUC 8-22 to glioma cells.

By means of immunodiffusion and immunoelectrophoresis tests the McAbs MUC 7-22, MUC 8-22, MUC 10-22, MUC 11-22, MUC 14-22 and MUC 15-22 were 
TABLE 1

REACTIVITY OF MONOCLONAL ANTIBODIES AGAINST HUMAN ASTROCYTOMAS WITH HUMAN CELLS AND TISSUES OF DIFFERENT ORIGIN ESTIMATED BY THE INDIRECT IMMUNOPEROXIDASE METHOD

\begin{tabular}{|c|c|c|c|}
\hline \multirow{2}{*}{$\begin{array}{l}\text { Tissue or } \\
\text { cell type }\end{array}$} & \multicolumn{3}{|c|}{ Murine monoclonal antibodies } \\
\hline & MUC 1-3/MUC 5-3 & MUC 7-22/MUC 15-22 & MUC 2-63 \\
\hline $\begin{array}{l}\text { 1. Normal brain } \\
\text { (1. occip., m., } 70 \text { yrs })(1)\end{array}$ & + & - & - \\
\hline $\begin{array}{l}\text { 2. Embryonic brain cells } \\
\text { (brain anlage, } 9 \text { wks) (1) }\end{array}$ & + & + & + \\
\hline $\begin{array}{l}\text { 3. Fetal brain cells } \\
\text { ( } 22 \text { and } 24 \mathrm{wks})(2)\end{array}$ & + & + & + \\
\hline $\begin{array}{l}\text { 4. Blood monocytes } \\
\text { (healthy donors) (5) }\end{array}$ & - & - & - \\
\hline 5. Lymphoma (2) & - & - & - \\
\hline 6. Colon carcinoma (3) & + & $(+)^{*}$ & - \\
\hline 7. Breast carcinoma (4) & - & $(+)$ & - \\
\hline 8. Gastric carcinoma (3) & n.t. & - & - \\
\hline 9. Renal carcinoma cells (2) & + & - & - \\
\hline 10. Teratocarcinoma (testis) (1) & n.t. & $(+)$ & $(+)$ \\
\hline 11. Meningioma (endotheliomatous) (4) & - & $(+)$ & - \\
\hline 12. Meningioma (haemangioblastic) (1) & - & - & - \\
\hline 13. Melanoma (8) & + & + & + \\
\hline 14. Neuroblastoma cells (1) & + & + & + \\
\hline 15. Glioma (42) & + & + & + \\
\hline
\end{tabular}

* A few positive cells; n.t., not tested; no. tested in parentheses.

identified to be $\mathrm{IgG}_{2 \mathrm{a}}$. The isotype of MUC 2-63 antibodies was $\operatorname{IgG}_{1}$ according to gel diffusion and microtitration ELISA subtyping system.

Binding properties of McAbs to fixed and paraffin embedded tissue sections

The immunoreactions of the gliomas tested with the antibodies MUC 7-22 to MUC 15-22 are summarized in Table 2. All gliomas studied bound McAbs in different patterns. In most instances tumors contained small areas of positive cells or single positive cells disseminated in the tumor tissue. In 2 cases tumors had large regions of positive cells (more than $50 \%$ of the neoplastic cells). Material fixed with methanol/ acetone or Karnovsky's solution and embedded in paraffin $\left(45^{\circ} \mathrm{C}\right)$ contained significantly more stained cells as compared to preparations after fixation with Bouin's fixative (Table 3). Tumor cells in areas with characteristic architectural and cytological features of well differentiated astrocytomas were usually stained and showed different staining intensities. In all positive cells the reaction product was localized in cytoplasm, whereas nuclei were ordinarily negative. No staining was obtained within the intercellular spaces, mononuclear infiltrates, necrosis, abnormal stromal reactions, vascular proliferations, and normal brain areas bordering on tumor tissue. 


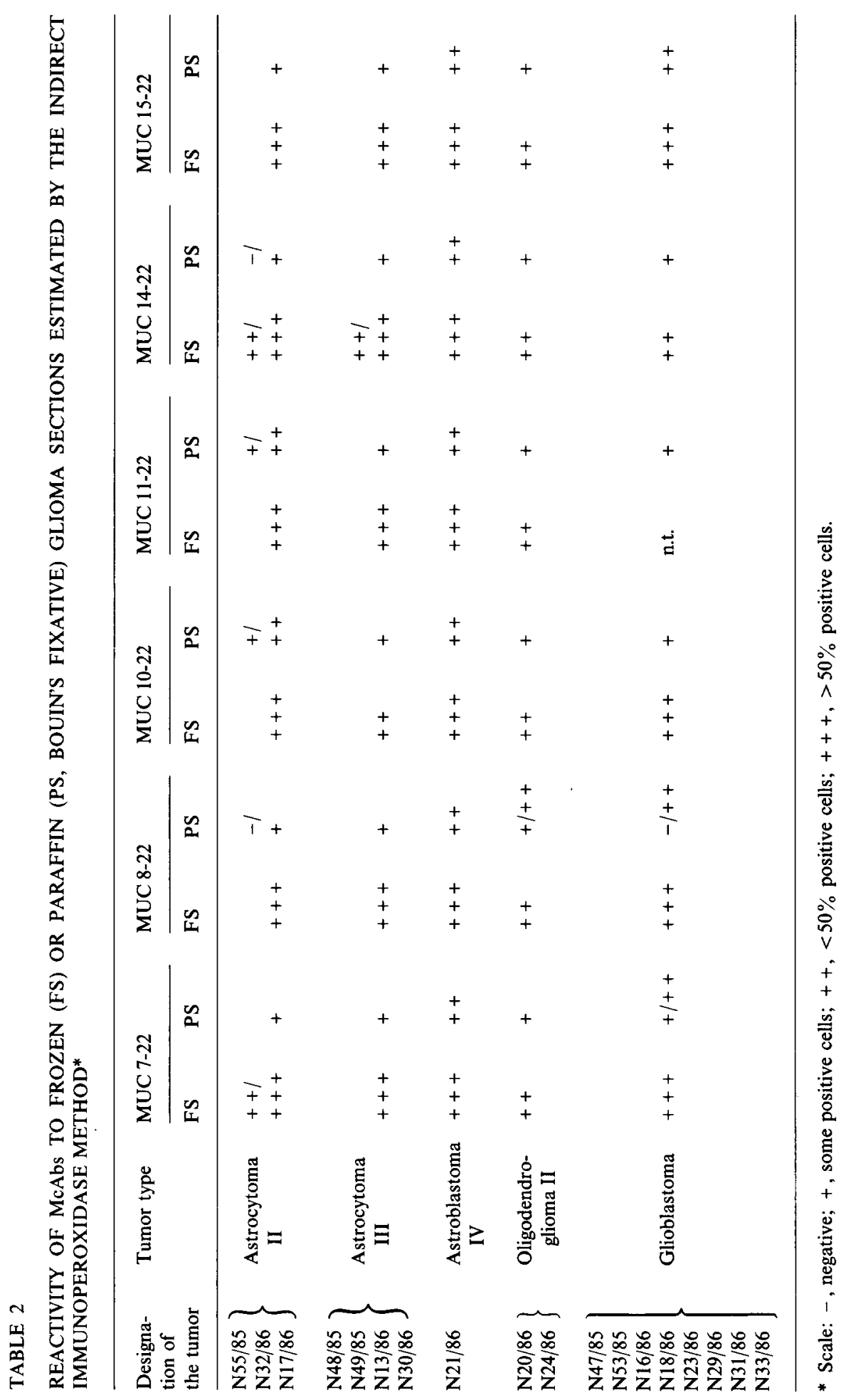


TABLE 3

REACTIVITY OF THREE MONOCLONAL ANTIGLIOMA IMMUNOGLOBULINS TO SELECTED GLIOMA TISSUE UNDER VARYING CONDITIONS BY INDIRECT IMMUNOPEROXIDASE METHOD*

\begin{tabular}{|c|c|c|c|c|c|c|c|}
\hline \multirow[t]{2}{*}{$\begin{array}{l}\text { Monoclonal } \\
\text { products }\end{array}$} & \multirow[t]{2}{*}{$\begin{array}{l}\text { Antibody } \\
\text { isotype }\end{array}$} & \multirow[t]{2}{*}{$\begin{array}{l}\text { Target } \\
\text { tumors }\end{array}$} & \multicolumn{2}{|c|}{ Frozen sections } & \multicolumn{3}{|c|}{$\begin{array}{l}\text { Stability of glioma antigen(s) in paraffin } \\
\text { sections after fixation with }\end{array}$} \\
\hline & & & Native & $\begin{array}{l}\text { Acetone } \\
\text { fixed }\end{array}$ & $\begin{array}{l}\text { Bouin's } \\
\text { fixative }\end{array}$ & $\begin{array}{l}\text { Methanol/ } \\
\text { acetone }\end{array}$ & $\begin{array}{l}\text { Karnovsky's } \\
\text { fixative }\end{array}$ \\
\hline MUC $8-22$ & $\operatorname{IgG} 2 \mathrm{a}$ & $\begin{array}{l}\text { N23/86 } \\
\text { N24/86 } \\
\text { N29/86 } \\
\text { N31/86 } \\
\text { N32/86 } \\
\text { N33/86 }\end{array}$ & $\begin{array}{l}+++ \\
++ \\
+++ \\
+++ \\
+++ \\
+++\end{array}$ & $\begin{array}{l}++ \\
++ \\
++ \\
+++ \\
++ \\
+++\end{array}$ & $\begin{array}{l}+ \\
++ \\
++ \\
++ \\
- \\
-\end{array}$ & $\begin{array}{l}+ \\
+ \\
++ \\
++ \\
+++ \\
+++\end{array}$ & $\begin{array}{l}+ \\
++ \\
++ \\
++ \\
- \\
+\end{array}$ \\
\hline MUC $10-22$ & $\operatorname{IgG} 2 \mathrm{a}$ & $\begin{array}{l}\text { N23/86 } \\
\text { N24/86 } \\
\text { N29/86 } \\
\text { N31/86 } \\
\text { N32/86 } \\
\text { N33/86 }\end{array}$ & $\begin{array}{l}+++ \\
++ \\
+++ \\
+++ \\
+++ \\
+++\end{array}$ & $\begin{array}{l}+ \\
+ \\
+++ \\
++ \\
+++ \\
+++\end{array}$ & $\begin{array}{l}+ \\
++ \\
++ \\
++ \\
+ \\
+\end{array}$ & $\begin{array}{l}++ \\
+ \\
++ \\
++ \\
+++ \\
+++\end{array}$ & $\begin{array}{l}+ \\
+ \\
\text { n.t. } \\
++ \\
+ \\
-\end{array}$ \\
\hline MUC 14-22 & IgG2a & $\begin{array}{l}\text { N23/86 } \\
\text { N24/86 } \\
\text { N29/86 } \\
\text { N31/86 } \\
\text { N32/86 } \\
\text { N33/86 }\end{array}$ & $\begin{array}{l}+++ \\
++ \\
++ \\
+++ \\
+++ \\
+++\end{array}$ & $\begin{array}{l}++ \\
+ \\
++ \\
+++ \\
\text { n.t. } \\
+++\end{array}$ & $\begin{array}{l}+ \\
+ \\
+ \\
++ \\
++ \\
++\end{array}$ & $\begin{array}{l}++ \\
+ \\
+ \\
++ \\
+++ \\
+++\end{array}$ & $\begin{array}{l}+ \\
++ \\
+ \\
++ \\
- \\
+\end{array}$ \\
\hline
\end{tabular}

* Scale: - , negative; + , some positive cells;,$++<50 \%$ positive cells;,$+++>50 \%$ positive cells.

Binding properties of McAbs to glioma cryosections

The characteristic binding design of McAbs MUC 7-22 to MUC 15-22 investigated on glioma frozen sections is shown in Table 2. All 6 McAbs bound intensely to all tumor specimens tested. Moreover, relative binding activities of the McAbs were not comparable among cryosections and paraffin preparations. Although the number of immunostained cells using a panel of McAbs differs from tumor to tumor, it is evident that cryosections contained throughout essentially more cells with recognizable antigenic determinants than the paraffin embedded material. Strong cross-reactivities were found with all gliomas, particularly with astrocytomas as listed in Table 2.

Binding properties of McAbs to glioma cells and embryonic brain cells cultured in vitro

The series of cell cultures tested include short-term cultures as well as permanent tumor cell lines. As shown in Table 4, all McAbs bound with high capacity to cells derived from human gliomas, neuroblastomas, melanomas and from human embryonic brain anlage. No reaction was observed with non-neuroectodermal cell lines tested (Table 4) and with peripheral blood mononuclear cells. 


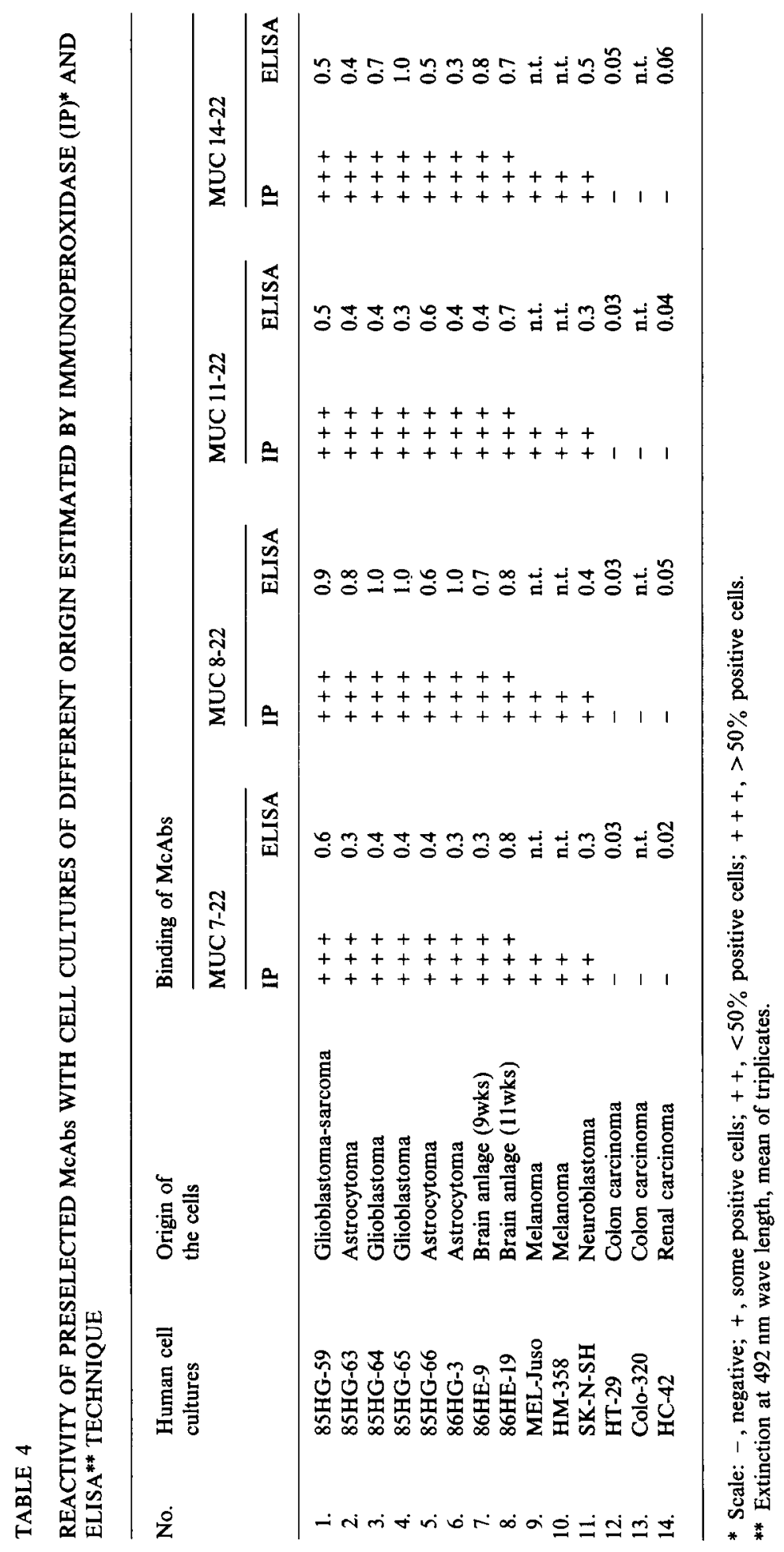




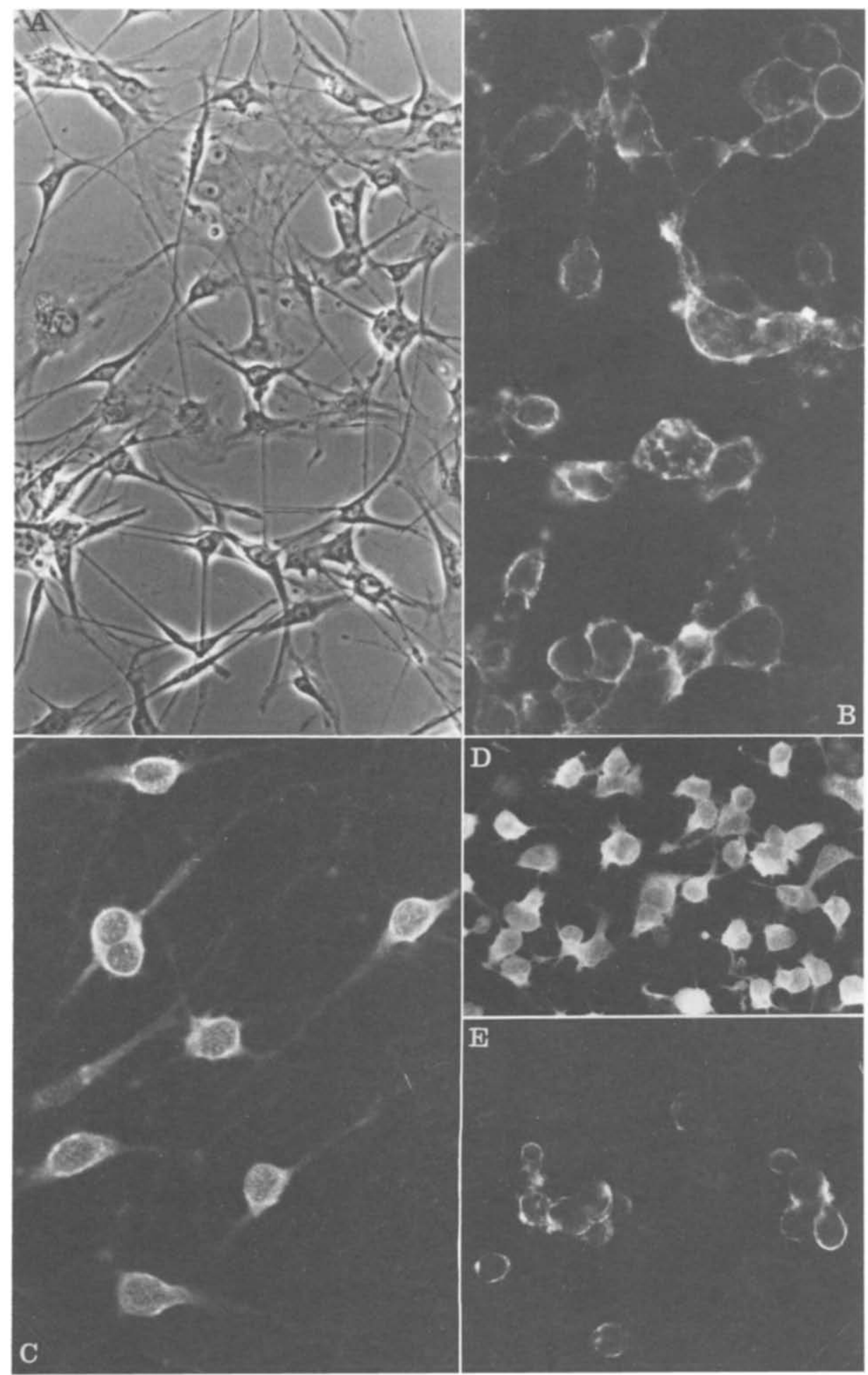


Concluding from the extinction data obtained by ELISA the antibodies MUC 8-22 and MUC 14-22 react strongly with the 2 glioblastoma cell lines (85HG-64, $85 \mathrm{HG}-65$ ) and in a lesser intensity with the rest of the tested glioma cultures. Strong binding was also observed with embryonic cells of different origin and especially with those from brain anlage.

The cellular distribution of glioma associated antigen(s) reacting with selected McAbs was studied by indirect immunofluorescence procedure on frozen sections of glioma tissue and also on cell cultures (Fig. 1). In general, the labelling with MUC 2-63 antibody was very high and the fluorescent structures were localized predominantly on the cell surface and occasionally in the cytoplasm of native cells. On the other hand, the epitopes reacting with MUC 7-22 to MUC 15-22 were confined mainly to the cytoplasm near the cell membrane. Particularly in acetone-fixed cells labelling of cytoplasmic organelles with MUC 7-22 to MUC 15-22 was remarkably strong, although unfixed cells were unlabelled or only marginally labelled.

\section{Binding properties of McAb to glioma cells in flow cytometry analysis}

Flow cytometry analysis gave an interesting staining pattern showing the heterogeneity of surface expression of the recognized antigen(s). As shown in Table 5 the percentage of stained cells differs from 16 to $65 \%$ when our set of McAbs is tested on various glioma cell lines. Fig. 2 demonstrates the recognition pattern of MUC 7-22 to MUC 15-22 on the cell line 85HG-65.

\section{DISCUSSION}

The results presented here indicate that a series of hybridomas originated by fusing of X63-Ag8.653 murine myeloma cells with mouse splenocytes of mice sensitized against human astrocytomas. A number of the hybridomas obtained produced no detectable antibodies or they stopped producing them after a few in vitro passages. The majority of the immunoglobulin-producing hybridomas, however, secretes antibodies binding a large number of normal and transformed human cells.

Seven hybridoma clones (MUC 7-22 to MUC 15-22 and MUC 2-63) obtained using a novel immunization schedule were selected according to binding properties of their products with human neuroectodermal tissue under certain conditions. Namely, the binding capability of the McAbs was tested on sections of fresh and paraffinembedded $\left(45^{\circ} \mathrm{C}\right)$ material as well as on short-time in vitro cultured brain and glioma cells. According to the results of different binding tests, the monoclonal products MUC 7-22 to MUC 15-22 recognized antigenic determinants which were commonly expressed on neoplastically transformed glia cells, normal cells of the embryonic brain anlage and a few cells in brain areas next to the tumor tissue.

Fig. 1. Glioma cell line derived from a human astrocytoma grade III consists entirely of bipolar or stellate cells (A, 42nd passage). Binding capacity of MUC 2-63 and MUC 8-22 monoclonal antibodies to glioma cells by indirect immunofluorescence staining under different conditions (B-E). The unfixed cells (B: monolayer; E: cytospin preparation) show binding for MUC 2-63 on the cell membrane. Acetone-fixed glioma cells (C: monolayer; D: cryosection) tested for reactivity with MUC 8-22 antibody demonstrate fluorescent structures mainly in the cytoplasm. (A-C: $\times 200 ; \mathrm{D}, \mathrm{E}: \times 125)$. 


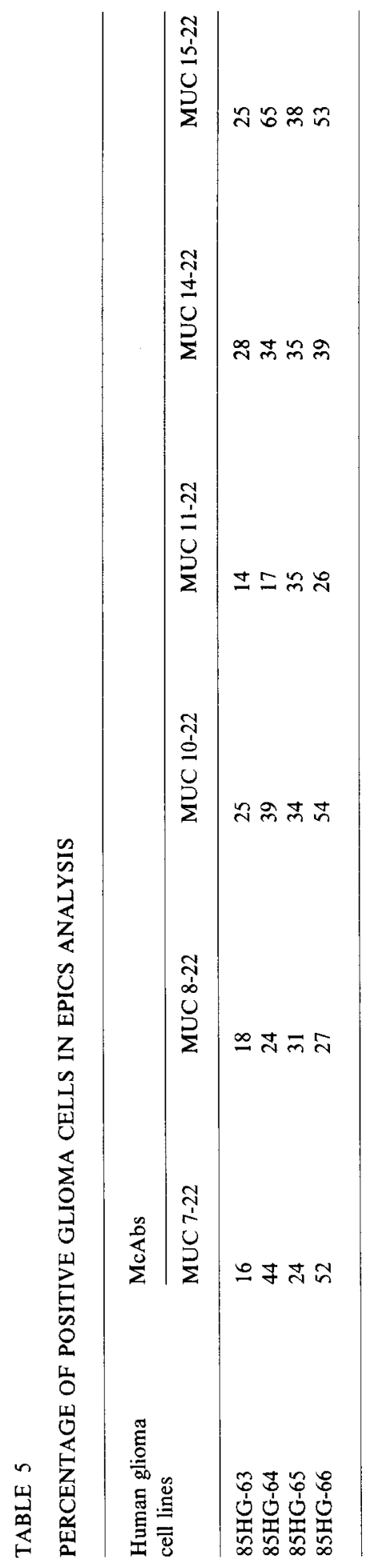




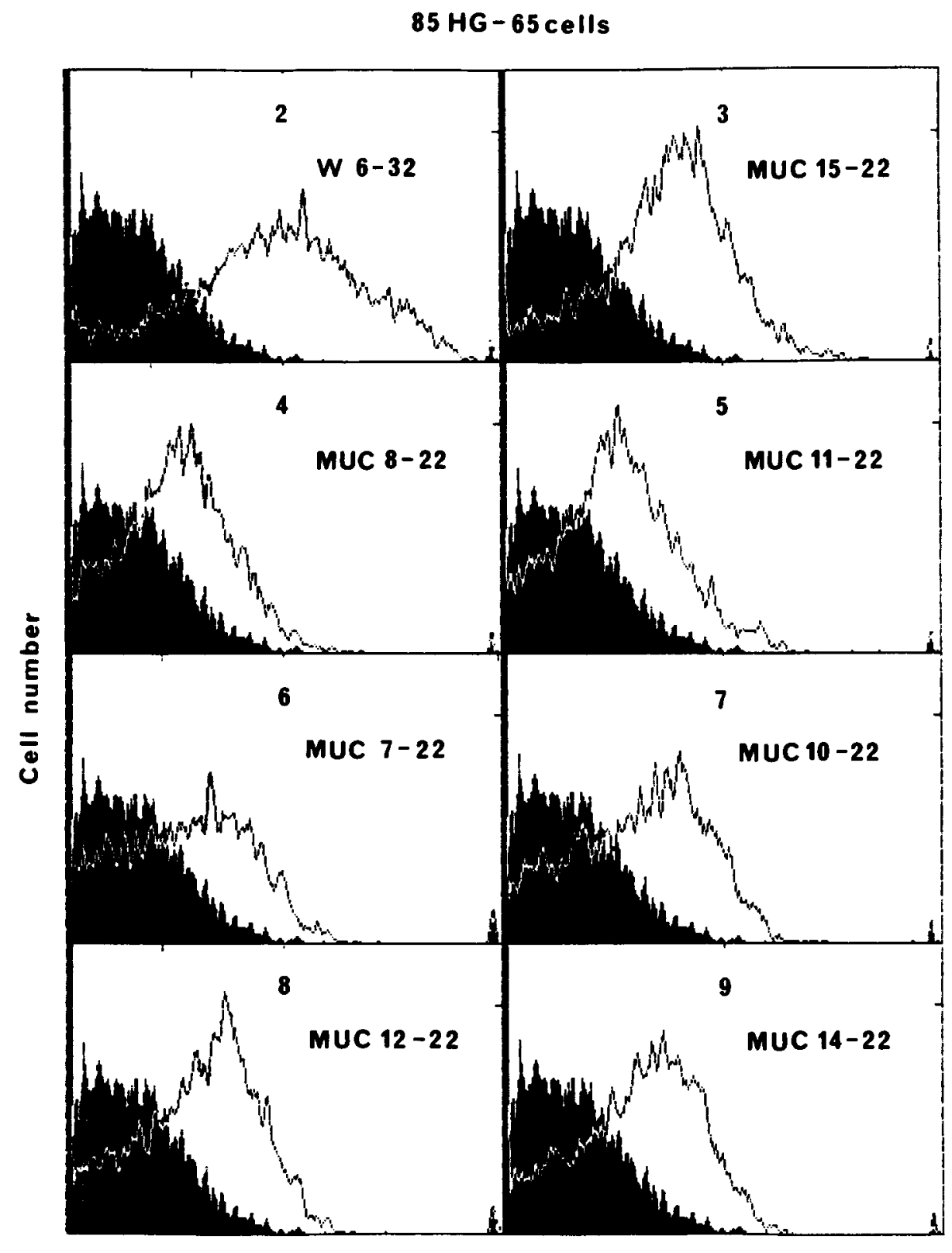

Fluorescence intensity

Fig. 2. Fluorescent-activated cell sorting profiles of glioma associated antigens on $85 \mathrm{HG}-65$ human brain tumor cells recognized by the W 6-32 (against human class-I antigens) and the MUC antibodies (MUC 15-22: 49\%; MUC 8-22: 31\%; MUC 11-22: 35\%; MUC 7-22:24\%; MUC 10-22: 34\%; MUC 12-22: $38 \%$; MUC 14-22: $35 \%$ positive cells). Evaluated against the isotype control UPC 10 (dark field). 
The binding results using paraffin and frozen sections as well as cell cultures indicated that an ideal screening method that allows the identification of glioma antigens in native form, does not exist so far (Roholl et al. 1985; Taub et al. 1985). As shown in Table 3 tissue sections from material fixed with various chemicals and embedded in paraffin have their limitations. Fixation with coagulative fixatives (Bouin's) or crosslinkers (e.g., formaldehyde) obviously alters tumor-associated membrane antigens so that they mostly cannot be recognized by monoclonal antibodies. From all fixatives used in this study methanol/acetone or the Karnovsky paraformaldehyde/glutaraldehyde mixture and paraffin embedding at $45^{\circ} \mathrm{C}$ have been shown to be acceptable procedures. It is also apparent that air-dried, frozen sections (Kemshead and Coakham 1983; Coakham et al. 1985) or cryosections mounted on slides, using a combination of drying at room temperature and fixation with cold acetone $\left(5 \mathrm{~min}, 4^{\circ} \mathrm{C}\right)$, are to be preferred to paraffin sections. However, the cytological evaluation of immunostained frozen sections can certainly introduce considerable difficulties in the cell characterization and particularly in the distinction between normal, reactive and neoplastically transformed cells. Depending on the binding behaviour with human normal and malignant tissue of different organs, the generated antibodies could be divided into 2 groups; the first group comprising of 5 antibodies (MUC 1-3 to MUC 5-3) shows reactivity against a large series of normal and tumor tissues. The second group of antibodies (MUC 7-22 to MUC 15-22 and MUC 2-63) differed from the former one by showing restricted reactivity essentially with neuroectodermal tumor cells as well as with embryonic and fetal brain cells of human origin.

The results of investigations comparing immunostained tumor sections under varying conditions suggest that the variability concerning the number of antibody binding cells in frozen sections and paraffin preparations is relative. The fact that each fixation and paraffin embedding led to remarkable reduction of positive cells indicate that many of tumor associated target determinants are destroyed by the used procedures.

Based on the binding pattern of the antibodies MUC 7-22 to MUC 15-22 and MUC 2-63 to gliomas, the conclusion seems justified that these McAbs recognize different epitopes. This was confirmed by immunostaining of frozen and paraffin preparations of the same tumor, and cell cultures as well (Fig. 1, Table 3). Moreover, the binding behavior of preselected McAbs to human tumors of different origin (Tables 1 and 2) indicated that neuroectodermal tumors share similar antigens as described for spontaneous (Seeger et al. 1981; Carrel et al. 1982; de Muralt et al. 1985) and experimental neurogenic tumors (Stavrou et al. 1983).

Particularly interesting is the observation that the McAbs obtained against astrocytomas (MUC 7-22 to MUC 15-22 and MUC 2-63) reacted not only with glioma cells but also with cells of the embryonic brain anlage, the fetal brain and other embryonic regions. Therefore, it is most likely that the antigens recognized by these antibodies represent oncoembryonal/oncofetal antigens expressed in cells during the prenatal period and also in brain tumor cells. These results correspond with observations reported by Wikstrand et al. (1982) and de Muralt et al. (1985).

The fact that McAbs directed against gliomas recognize molecules expressed in 
glioma cells as well as in embryonic and fetal cells and even in reactive astrocytes (de Muralt et al. 1985) does not limit the application of such antibodies for immunodiagnostic purposes. Regarding the histological and cytological examination of brain malignancies and the analysis of tumor cells in the cerebrospinal fluid (Coakham et al. 1985), well defined reagents, e.g. McAbs, provide valuable diagnostic tools.

Although immunohistochemical studies are still in a preliminary stage, they are creating new perspectives for an objective intraoperative diagnostic service, especially in cases where only small fragments of biopsy material are available. Moreover, McAbs directed against molecules restricted to embryonal/fetal tissue and re-expressed in malignant transformed brain cells may serve as carriers for radionuclides and cytostatic or cytotoxic agents in evaluation of in vivo diagnostic and therapeutic approaches as recently demonstrated for spontaneous and experimental neurogenic tumors (Bourdon et al. 1984; Epenetos et al. 1985; Stavrou et al. 1985, 1986a,b; Bullard et al. 1986). According to the different staining pattern of our McAbs recognizing up to $65 \%$ of the cells within a glioma line one has to consider the possibility to increase the amount of positive cells by using a combination of McAbs.

\section{ACKNOWLEDGEMENTS}

We are grateful to Mrs. D. Wallmann, Mrs. L. Döhle for excellent technical assistance and to Mrs. H. Schmid and Mrs. M. Lusos for preparing the typescript. We are indebted to Dr. H. Krämer and Dr. E. Koschade and their staffs for helpful cooperation. This work was financially supported by the Sturm-Foundation, Munich, the W. Sander-Foundation (Grant Sta 86.005.1) and the C. Bohnewand Fund for Cancer Research, University of Munich.

\section{REFERENCES}

Bourdon, M.A., R.E. Coleman, R.G. Blasberg, D.R. Groothuis and D.D. Bigner (1984) Monoclonal antibody localization in subcutaneous and intracranial human glioma xenografts: Paired-label and imaging analysis. Anticancer Res., 4: 133-140.

Bullard, D. E. and D. D. Bigner (1985) Applications of monoclonal antibodies in the diagnosis and treatment of primary brain tumors. J. Neurosurg., 63: 2-16.

Bullard, D.E., C. J. Adams, R. E. Coleman and D.D. Bigner (1986) In vivo imaging of intracranial human glioma xenografts comparing specific with non specific radiolabeled monoclonal antibodies. $J$. Neurosurg., 64: 257-262.

Carrel, S., N. de Tribolet and J.P. Mach (1982) Expression of neuroectodermal antigens common to melanomas, gliomas and neuroblastomas, Acta Neuropathol. (Berl.), 57: 158-164.

Coakham, H. B., J. A. Garson, J. T. Kemshead, E. Z. Harper and B. Brownell (1982) Monoclonal antibodies to uncultured human astrocytomas. J. Neuroimmunol., 3: 238.

Coakham, H. B., J. A. Garson, B. Brownell and J. T. Kemshead (1985) Diagnosis of cerebral neoplasms using monoclonal antibodies. Progr. Exp. Tumor Res., 29: 57-77.

Epenetos, A. A., N. Courtenay-Luck, D. Pickering, G. Hooker, H. Durbin, J.P. Lavender and C.G. McKenzie (1985) Antibody guided irradiation of brain glioma by arterial infusion of radioactive monoclonal antibody against epidermal growth factor receptor and blood group A antigen. Br. Med. J., 290: 1463-1466.

Jonak, Z. L. (1980) Isolation of monoclonal antibodies from supernatant by $\left(\mathrm{NH}_{4}\right)_{2} \mathrm{SO}_{4}$ precipitation. In: Kennett, R.H., T.J. McKearn and K. B. Bechtol (Eds.), Monoclonal Antibodies, Plenum Press, New York, pp. 405-406. 
Kearney, J.F., A. Radbruch, B. Liesegang and K. Rajewsky (1979) A new mouse myeloma cell line that has lost immunoglobin expression but permits the construction of antibody secreting hybrid cell line. J. Immunol, 123: 1548-1550.

Kemshead, J.T. and H.B. Coakham (1983) The use of monoclonal antibodies for the diagnosis of intracranial malignancies and the small round cell tumours of childhood. J. Pathol., 141: 249-257.

Köhler, G. and C. Milstein (1975) Continuous cultures of fused cells secreting antibody of predefined specificity. Nature (Lond.), 256: 495-497.

Krajewski, S., G. Schwendemann, M. Weizsăcker, W. Wechsler and N. de Tribolet (1986) Binding specificity of two monoclonal antiglioma antibodies: Immunocytochemical studies using a new embedding technique. Acta Neuropathol. (Berl.), 69: 124-131.

Lanier, L. L. and N. L. Warner (1981) Paraformaldehyd fixation of hematopoietic cells for quantitative flow cytometry (FACS) analysis. J. Immunol. Methods, 47: 25-30.

De Muralt, B., N. de Tribolet, A.-C. Diserens, D. Stavrou, J.P. Mach and S. Carrel (1985) Phenotyping of 60 cultured human gliomas and 34 other neuroectodermal tumors by means of monoclonal antibodies against glioma, melanoma and HLA-DR antigens. Eur. J. Cancer Clin. Oncol., 21: 207-216.

Posner, M.R., D. Antoniou, J. Griffin, S.F. Schlossman, and H. Lazarus (1982) An enzyme-linked immunosorbent assay (ELISA) for the detection of monoclonal antibodies to cell surface antigens on viable cells. J. Immunol. Methods, 48: 23-31.

Roholl, P.J.M., A.S.H. De Jong and F.C.S. Ramaekers (1985) Application of markers in the diagnosis of soft tissue tumours. Histopathology, 9: 1019-1035.

Schnegg, J. F., A.C. Diserens, S. Carrel, R. S. Accolla and N. de Tribolet (1981) Human glioma associated antigens detected by monoclonal antibodies. Cancer Res., 41: 1209-1213.

Seeger, R.C., H.M. Rosenblatt, K. Imai and S. Ferrone (1981) Common antigenic determinants on human melanoma, glioma, neuroblastoma and sarcoma cells defined by monoclonal antibodies. Cancer Res., 41: 2714-2717.

Sikora, K. and J. Phillips (1981) Human monoclonal antibodies to glioma cells. Br. J. Cancer, 43: 105-107.

Stavrou, D., A.P. Anzil and H. Elling (1978) Tumor specific fluorescent and complement-dependent cytotoxic antibodies in the serum of rats with chemically induced brain gliomas. Acta Neuropathol. (Berl.), 43: 111-117.

Stavrou, D., M. Hultén, A. P. Anzil and T. Bilzer (1980) The humoral antibody response of rats immunized with chemically modified syngeneic brain cells and glioma cells. Int. J. Cancer, 26: 629-637.

Stavrou, D., M. Hultén and T. Bilzer (1981) Chemical modification and antigenicity of glioma cells. Acta Neuropathol. (Berl.), Suppl. VII: 75-78.

Stavrou, D., Ch. Süss, T. Bilzer, T., U. Kummer and N. de Tribolet (1983) Monoclonal antibodies reactive with glioma cell lines derived from experimental brain tumors. Eur. J. Cancer Clin. Oncol., 19: 1439-1449.

Stavrou, D., W. Mellert, T. Bilzer, R. Senekowitsch, E. Keiditsch and P. Mehraein (1985) Radioimmunodetection of gliomas by administration of radiolabelled monoclonal antibodies. Experimental data. Anticancer Res., 5: 147-156.

Stavrou, D., W. Mellert, U. Mellert, E. Keiditsch, K. Bise and P. Mehraein (1986a) Growth inhibition of experimental glioma grafts by monoclonal antibody treatment. J. Cancer Res. Clin. Oncol., 112: 111-118.

Stavrou, D., H. Glässner, T. Bilzer, R. Senekowitsch, E. Keiditsch and P. Mehraein (1986b) Radioimaging of experimental glioma grafts using $\mathrm{F}\left(\mathrm{ab}^{\prime}\right)_{2}$-fragments of monoclonal antibodies. Anticancer Res., 6 : 897-904.

Taub, F., J. Satoh, C. Garzelli, K. Essani and A. L. Notkins (1985) Human monoclonal antibodies reactive with multiple organs. In E. G. Engleman (Ed.), Human Hybridomas and Monoclonal Antibodies, Plenum Press, New York.

Wikstrand, C.J. and D.D. Bigner (1982) Expression of human fetal brain antigens by human tumors of neuroectodermal origin as defined by monoclonal antibodies. Cancer Res., 42: 267-275. 